\title{
The impact of etnocontructivism in social affairs on pedagogic competencies
}

\author{
Syahrial Syahrial $^{1}$, Asrial Asrial ${ }^{2}$, Dwi Agus Kurniawan ${ }^{3}$, Faizal Chan ${ }^{4}$, Ahmad Hariandi ${ }^{5}$ Reza \\ Aditya Pratama ${ }^{6}$, Putut Nugrogo $^{7}$, Retno Septiasari ${ }^{8}$ \\ 1,2,4,5,6,7,8 Department of Elementarry Teaching and Education, Universitas Jambi, Indonesia \\ ${ }^{3}$ Department of Physics Education, Universitas Jambi, Indonesia
}

\section{Article Info}

Article history:

Received Jun 6, 2019

Revised Jul 13, 2019

Accepted Aug 25, 2019

\section{Keywords:}

Elementary school teacher

Ethnoconstructivism

Pedagogic competence

\begin{abstract}
Teacher Competency Test is a test of mastery of professional and pedagogic competencies in the cognitive domain as a basis for establishing continuous professional development activities and part of teacher assessment. The test is a source and as a material for mapping the competencies that a teacher has regarding professional and pedagogical competence in an area. The low competence of the pedagogical field shows that teachers are not professional. Therefore the teacher will find it difficult to be able to provide a good pursuit of students. One way to improve the competence of teachers in pedagogic fields is by increasing teacher understanding and knowledge of local wisdom in learning. The essence of local and national cultural values in the education curriculum is now a bustling thing to be talked about by the people of Indonesia. Social ethnoconstructivism is able to be a solution amid the current developments and cultural shifts. This study wants to see how high the impact of ethnoconstuctivistic knowledge on teacher pedagogical competencies. In addition, age and gender are also separate discussions to see their influence on pedagogical competence. This research uses descriptive qualitative research. Samples in this study were elementary school teachers in three districts/cities in Jambi Province. The results show that teachers' ethnoconstructivism knowledge has an influence on the teacher's pedagogical competence. The age of a teacher also has an impact on pedagogical competence, but gender does not affect the teacher's pedagogical competency.
\end{abstract}

Copyright $@ 2019$ Institute of Advanced Engineering and Science. All rights reserved.

\section{Corresponding Author:}

Asrial Asrial,

Department of Teaching and Education

Universitas Jambi,

Lintas Jambi-Muaro Bulian Street KM. 15, 36361, Jambi, Indonesia

Email: porigih@gmail.com

\section{INTRODUCTION}

Education is a processor effort carried out by someone to gain knowledge, skills, and habits in life. Education is a very important activity, with the behavior and knowledge for the better [1]. Education is a process for acquiring and instilling skills carried out by students [2]. In addition, according to [3] Education is a process of order in order to influence students to be able to adjust as well as possible with their environment and by doing so will cause changes in themselves that allow them to function in social life.

One of the teachers has a position as a professional, as a professional, the teacher is required to have four compulsory competencies, namely pedagogic competence, professional competence, social competence, and emotional competence. In practice to map so far where teachers have the competence, the government of Indonesia me to do periodic tests of the teachers through the Teacher Competency Test (UKG). According to the Minister of Education and Culture of the Republic of Indonesia No.57 of 2012 that "Teacher Competency 
Test (UKG) is a test of mastery of professional and pedagogic competencies in the cognitive realm as the basis for establishing continuous professional development activities and part of teacher assessment". The aim of the government to hold a UKG is to see teacher competency mapping by region. "The difference between UKG and PLPG, UKG is so far used for knowing the teachers' control of their competence as a professional teacher, their remembering capability and their intelligence which is different from their teachers and their different circumstances from the different districts" [4].

$\mathrm{UKG}$ is a source and as a material for mapping the competencies that a teacher has regarding professional and pedagogical competence in an area. Based on the results of the 2017 UKG elementary school teacher conducted by the Ministry of Education and Culture, Jambi Province only obtained an average score of 49.2. This value is far from the value of the Indonesian national average which is at number 62.22.

The low competence of the pedagogical field shows that teachers are not professional. Therefore the teacher will find it difficult to be able to provide a good pursuit of students. Pedagogic competence has a very important role that concerns matters of principle in education. [5] "The pedagogical knowledge is not exactly the same thing as knowledge of subject matter. However, they are never intimately linked. This is because the teachers' mastery and use of pedagogical knowledge in the classroom will indicate the depth of their competence in the use of their knowledge of subject matter." By having good pedagogical competence, the teacher automatically fulfills professional competencies, personality, and emotional competencies. Professional teachers will have an impact on effective learning that can be seen from teacher ingenuity, mastery of material, and strong commitment. [5] Saw basic knowledge of related subject matters as required conditions for effective teaching. Thus she continued that effective teaching implant teacher integrity, sound knowledge of the subject matter, professional commitment, imagination and sound knowledge of the underlying psychology, the history, sociology, and philosophy of the subject matter. The teacher also has the duty to be able to see the potential of the students. Educational physiologists turned their attention with great effects to the study of aptitude and achievement and to the social and motivational aspects of education, but are not concerned with the intellectual structure of class activities [6].

The importance of the position of pedagogic competencies for teachers, the improvement and development of competencies in the pedagogic field for teachers is something that is very necessary. The improvement efforts can be done in various ways. One way to improve the competence of pedagogical teachers is by increasing teacher understanding and knowledge about local wisdom in learning.according to [7] that "Pedagogical Competence of teachers must understand the characteristics of students from physical, moral, social, cultural, emotional and intellectual aspects". This means that the teacher must understand the socio-cultural and socio-cultural background of the students, as part of the teacher's pedagogical competence. Carrying out learning by following the cultural background and local wisdom of students means being part of pedagogical competence.

The essence of local and national cultural values in the education curriculum is now a bustling thing to be talked about by the people of Indonesia. The concept of Indigenous Knowledge serves as a framework for how relevant and easy the process of developing cultural competencies can be adapted for integration throughout the profession [8]. The curriculum is rooted in local culture and nation, meaning that the curriculum must provide opportunities for students to learn from their culture and nationally about various important life values. A teacher must be able to understand the knowledge of the culture that is close to the environment of students. One form of cultural knowledge that must be understood by a teacher is ethnoconstructivism in the social field. Indeed a human being is a social creature that cannot be separated from his social environment. This is what makes a teacher must understand and be able to teach it to students.

Social ethnoconstructivism is able to be a solution amid the current developments and cultural shifts. [9] Constructivist approach group work is considered to improve student achievement and social skills of students. The entry of foreign culture through the development of technology in a sense will certainly affect the habits and behavior patterns of society, including children. By having ethnoconstructivism understanding, the child will be able to filter out all the forms of the foreign culture he meets, or even be able to be properly assimilated in his daily life. Basically, a child can not lose his national identity. This is what makes the teacher have an obligation to be able to provide good ethnoconstructivism understanding to the students. [9] Despite its benefits, when teachers are interested in effective planning practices (CLP) in advance for effective class practices.

Teachers with good pedagogical competence will be able to teach cultural values to students well too. But if it is reviewed by age, the teacher clearly has different pedagogical competencies. The study of how significantly the influence of a teacher's age on his competence is very rare. The reason according to Sloane \& Kelly [10] is that most developed countries like America don't care about the age of a teacher. But in this study, it will be seen whether the teacher's age influences the teacher's pedagogical competence. [11] It is a general thought that as an advanced and designation is promoted, teachers lose the enthusiasm to teach. 
But the age and experience of a teacher can go hand in hand. The older the age of a teacher, the better the experience; hopefully they can see the potential of their students.

Besides age, gender will also be seen whether it will also affect the competence of a teacher. Akiri and Ugborugbo [12] found that there was a significant relationship between teacher gender and student academic achievement. Like most other countries, there are more female teacher statistics than male teachers. Many studies discuss the influence of gender on teacher pedagogical competencies. According to [13], the study so far illustrates that women are somewhat better than men in teaching to elementary school students. [14] Teaching is one of the most eligible jobs for women, female teachers are considered as ideal partners, so girls are directed to teach in their career choices consciously or unconsciously. But it is not impossible for a man to be a good teacher or have good pedagogical competence. Hence gender equality in the world of education will be another concern for the government.

\section{RESEARCH METHOD}

The research method used in this study is a descriptive research method. Descriptive research describes attitudes and behaviors observed during investigations, descriptive research takes place in nature, real-life settings [15]. The descriptive approach is carried out to see the extent to which ethnoconstructivism knowledge of elementary school teachers as well as to find out the pedagogical competencies of elementary school teachers. Then look at the influence of ethnononstructivism in the social field on teacher pedagogical competencies. The population in this study were elementary school teachers in the Jambi province of Indonesia, the sample of which were elementary school class teachers in Batanghari District, Muaro Jambi District, and Jambi City as many as 691 primary school classroom teachers. The sampling technique used is cluster sampling. [16] Cluster sampling a type of random sample that is used to cover wide geographic units which are randomly selected and then sampled from the aggregated units or clusters. Cluster sampling was chosen to facilitate data collection from extensive research areas. Data collection in this study uses questionnaire instruments, multiple choice, interviews, and documentation.

The flow of this research began by giving questionnaires to elementary school class teachers. The type of questionnaire used in this study is a closed type questionnaire where the answer option has been determined. Questionnaire is the answer to the questionnaire [17]. The purpose of the questionnaire is to look at the level of ethnoconstructivism knowledge of elementary school class teachers. Below this is a categorization table of value ranges for questionnaires, where there are four categories, namely very good, good, not good, and not good see in Table 1.

Table 1. Categorization of the questionnaire range

\begin{tabular}{cc}
\hline Category & Value range \\
\hline Very Good & $47-57$ \\
Good & $36-46$ \\
Fairly Good & $25-35$ \\
Poor & $14-24$ \\
\hline
\end{tabular}

Data from the questionnaire results then be analyzed using SPSS Software to then be processed into descriptive statistics. Descriptive data are in the form of mean, median, mode, percentage, and frequency. Next is a multiple choice test question that is distributed to elementary school class teachers with the answer options as many as four options. Multiple choice questions are conducted in order to see high and low-level pedagogic competency levels of elementary school teachers. Table 2 shows categorization the ranges of values for multiple choice tests, where there are four categories, namely very good, good, not good, and not good.

Table 2. Categorization of the range of multiple choice questions

\begin{tabular}{cc}
\hline Category & Value Range \\
\hline Very Good & $76-100$ \\
Good & $51-75$ \\
Fairly Good & $26-50$ \\
Poor & $0-25$ \\
\hline
\end{tabular}

Multiple choice test questions data were analyzed using descriptive statistics. Then the researcher continued collecting data using a structured interview instrument. Interviews were conducted for low-class 
teachers, namely teachers in grades 1,2 , and 3 and high-class teachers, namely teachers in grades 4, 5, and 6 . The purpose of the interview was to strengthen questionnaire results and MCQs.Then the researcher conducted a document analysis in the form of a learning implementation plan to strengthen the questionnaire results data, multiple choice questions, and the results of interviews.

For the results of interviews and documentation analysis using Miles and Huberman analysis techniques. Analysis as three flows of combined activities: condensation of data, display of data, and approval/verification [18]. The step taken is to display the data from the interview and document analysis, then reduce it to sort the results of the research data, and the last is to draw conclusions.

\section{RESULTS AND DISCUSSION}

Data shows the level of teacher knowledge about ethnoconstivism. [19] Culture is a mode that applies to explain individuals or group variations so that the behavior concerns the difference between business behavior and its actual significance. Cultural competence involves not only recognizing the client's culture and influence but also being able to provide culturally congruent services [20]. Culture can be taught to students by teaching them the closest things. [21] Constructivism is "trivial" in Glasersfeld which is intended to teach the accepted scientific knowledge in traditional terms. Constructivist is one of the learning methods that are very compatible with cultural education. The constructivist learning processes support students' active participation, knowledge construction, and deep learning, encourages students to think and act independently, and encourage permanent learning [22]. Pedagogic competence is a way of teaching, for curriculum and evaluation in learning, this ethno relationship with pedagogic competence is how teachers can develop a curriculum based on local wisdom values (Ethno) of competencies and indicators developed. The extension of pedagogic content can be seen from the extent to which the teacher understands the substance of the curriculum based on the value of local wisdom (ethno) in Jambi. Constructivism is one approach that can be done to teach cultural education [22].

\subsection{Ethnoconstuctivistic knowledge}

From the Table 3, it can be seen that from 691 teachers, 261 male teachers and 430 female teachers with a percentage of the results of male low-grade ethnoconstivism knowledge teachers only $5 \%$ are in very good category. Then for male teachers who teach in the high class have a percentage in ethnoconstructiveism knowledge only $4 \%$ are the excellent category.

Table 3. Results of questionnaire for ethnoconstuctivistic knowledge

\begin{tabular}{|c|c|c|c|c|c|c|c|}
\hline \multicolumn{5}{|c|}{ Male } & \multicolumn{3}{|c|}{ Female } \\
\hline & category & Frequency & $\%$ & & category & frequency & $\%$ \\
\hline \multirow{5}{*}{$\begin{array}{c}\text { low grade } \\
\text { teacher }\end{array}$} & Very Good & 8 & 5 & \multirow{4}{*}{$\begin{array}{c}\text { low grade } \\
\text { teacher }\end{array}$} & Very Good & 22 & 11 \\
\hline & Good & 49 & 30 & & Good & 14 & 7 \\
\hline & Fairly Good & 31 & 19 & & Fairly Good & 79 & 38 \\
\hline & Poor & 74 & 46 & & Poor & 92 & 44 \\
\hline & total & 162 & 100 & \multicolumn{2}{|r|}{ total } & 207 & 100 \\
\hline high class & Very Good & 4 & 4 & high class & Very Good & 34 & 15 \\
\hline \multirow[t]{4}{*}{ teacher } & Good & 17 & 17 & teacher & Good & 21 & 9 \\
\hline & Fairly Good & 42 & 42 & & Fairly Good & 82 & 37 \\
\hline & Poor & 36 & 37 & & Poor & 86 & 39 \\
\hline & & 99 & 100 & & Total & 223 & 100 \\
\hline
\end{tabular}

While for female teachers who teach in the lower classes having ethnoconstructiveism knowledge is $44 \%$ in the bad category. Female teachers who teach in the high class have ethnoconstructiveism knowledge in the bad category are as much as $39 \%$.

Pedagogic competence is the ability to manage student learning which includes an understanding of students, planning, and implementing learning, evaluating learning outcomes, and developing students to explore the various potentials they have. Teachers' pedagogical competence is the ability to manage learning, which includes planning, implementation, and evaluation of learning outcomes of learners. These competencies should be owned by every teacher in order to achieve success in learning and teaching [23]. Pedagogical competencies have been respected either as an ensemble of potential behaviors/capacities for efficient manifestations of activities or as a minimum professional standard, which professionals should reach [24]. 


\subsection{Pedagogical of primary school teacher}

The results were obtained using multiple choice test instruments can be seen in Table 4. From the Table 4, it can be seen that majority of teachers is female. Male low-class pedagogical competence is as many as $21 \%$ in the category of vey bad. For male teachers who teach in the high class as much as $19 \%$ fall into the very bad are 19 percent. While for female teachers who teach in the lower classes, the percentage of $41 \%$ is categorized as very bad. Then for female teachers who teach in the high class with a percentage of $24 \%$ in the very bad.

Table 4. Pedagogical results of primary school teachers

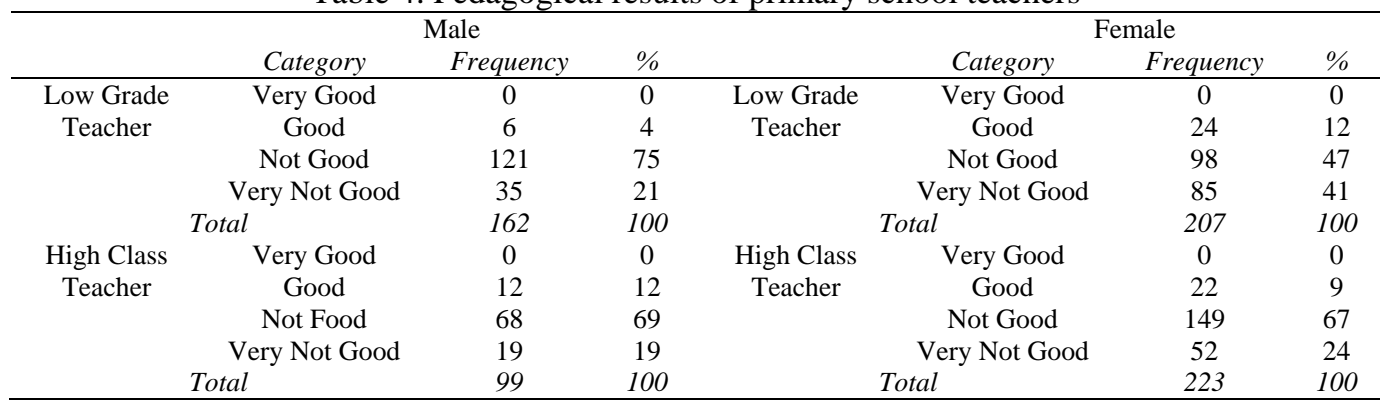

The result shows that the pedagogic competence of female teachers in Jambi Province is dominantly poor. If we look at it as a whole, the pedagogic competence of elementary school class teachers in Jambi Province falls into the poor category. With these results, it can be concluded that there is no significant difference between the pedagogic competence of male teachers and female teachers. This analysis shows that there are a number of productive teachers and women in secondary schools [25]. A teacher should have good competence because with good competence the teacher will be able to learn the material well. At the primary school level, the teacher does not only focus on one particular subject or subject. Elementary education majors are more similar to non-science majors in number and type of science coursework completed than they are to science majors and science education majors [26]. Intermediate education is between art and science, it's not art, for it is not a problem [27-29].

\subsection{Regression}

Looking at the results of pedagogic competencies that are reviewed based on age; it is found that the older the age of a teacher, the less pedagogical competency will be see in Table 5.

Table 5. Results of regression

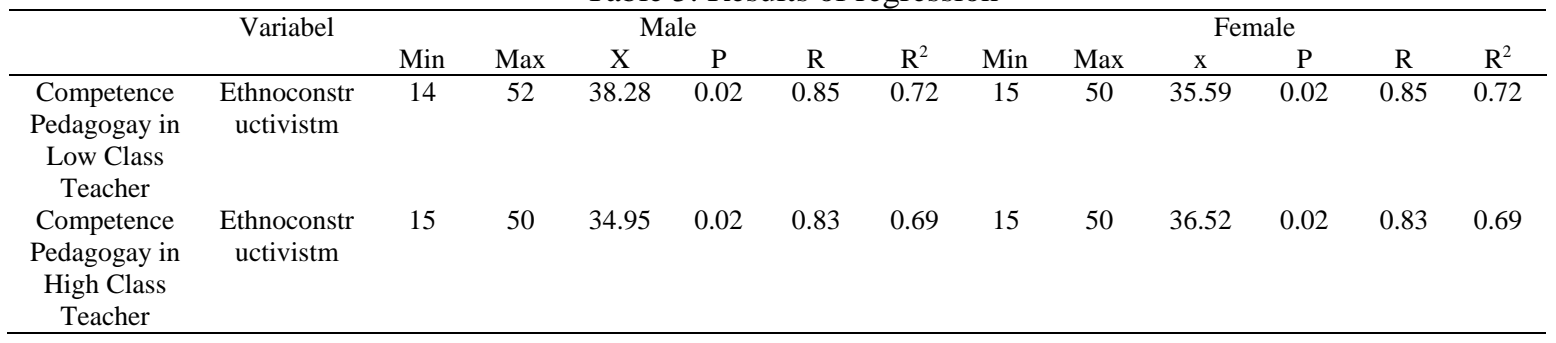

From Table 5, it can be seen that the min value for male teachers teaching in the lower class is 14, the maximum value obtained is 52 with an average value of 38.28. The sig value 0.02 is smaller than 0.05 , and it can be concluded that there is an influence between ethnoconstructivists and pedagogic competencies. The amount of influence is $72 \%$, and there are other influences beyond that as much as $28 \%$. For female teachers who teach in the lower classes obtain a minimum score of 15 , the maximum score is 50 . The average score obtained for female teachers teaching in the lower class is 35.59 . The sig value is 0.02 , where the value is smaller than 0.05 , so it can be concluded that there is an influence between ethnoconstructivists and teacher pedagogical competencies. The effect is $72 \%$ with another influence of $28 \%$.

Meanwhile for male teachers who teach in the high class get a minimal value of 15 and a maximum value of 50, with an average score of 34.95 . The sig value 0.02 which is smaller than 0.05 , it can be concluded if there is an influence between ethnoconstivism and pedagogic competence. The amount of 
influence is $69 \%$ with, $31 \%$ other influences. Whereas for female teachers who teach in the high class get a minimum score of 15 with the highest score of 50, and the average obtained is 36.52 . The sig value is 0.02 , this value is smaller than 0.05 , so it can be concluded if there is an influence between the ethnoconstructivist and the pedagogical competence of the teacher. The effect is $69 \%$, in addition, there are $31 \%$ other influences.

We have agreed that pedagogic competence is very important to be mastered by the teacher. The contribution of pedagogical competence is very important to make learning more effective [30, 31]. Many things can affect the pedagogical competence of a teacher other than ethnoconstructivism. One of them is the age of a teacher. [30] Older teachers who are more experienced in the areas where computers can support and expand teaching and learning. In addition, training also becomes another aspect that influences the pedagogical competence of the teacher. [32] Through discussion, the teachers collaborate to share their experiences and knowledge to clarify the learning objectives so that they can facilitate, and make many ways to improve their learning. The government has provided training to teachers to be able to improve pedagogical competencies. In addition, the use of technology also has an impact on teacher pedagogical competencies. The more benefits are obtained, the greater the chance someone will be issued; on the contrary, the lower the over benefits, the smaller the innovation is adopted. Therefore pedagogical activities that use ICT are most often adopted from the approved activities [33-35].

Besides quantitative data, qualitative data from interviews were also collected. As the opinion of the following teacher:

The first point is its implementation in student learning activities: (1) the implementation was explained first, for example, these children were adjusted first with lessons, like customs like marriage, and so if the Jambi marriage custom was like this, other marriage customs like this. But usually in class 6 that is detailed, if in the lower class just outlines. (Teacher interview, October 29, 2018); (2) for example, a bride in Mersam. Old chicken bride food cooked in my with a grudge for "penganten" from the place of the guynyo to the place of the girl Budaya Mersam can introduce the children to the name of the river in the sub-district of Mersam. On the Mersam River, there is a saving in the Netherlands. (Teacher interview, 30 October 2018); (3) Have applied. For example the time of mutual cooperation. Before entering the rubbish class, it must be collected and put into the trash can in the classroom and clean together, not just the picket. (Teacher interview, November 2, 2018); (4) Most about the environment, we introduce it first. This child already knows everything, for example, child marriage knows that parade is usually this once if here in the hamlet there are two times. Well, the clothes are different too, both in the hamlet and in the town of the city, they are also taught. (Teacher interview, November 4, 2018); (5) Most about the environment, we introduce it first, usually the wedding ceremony, festivity, Mawlid Prophet. (Teacher interview, November 5, 2018); (6) Maybe in the beginning learning would be linked before learning to enter material related to ethnosocial examples that exist in society. It's been a month for the material to be about economic activities. So being explained about economic activities is the same as livelihoods, the work of parents. But the child is still confused about the livelihoods in Bajubang. Even though it's been explained like a rubber tapper. (Teacher interview, November 7, 2018); (7) Class 2 tells students, ask what students are from the tribe? Because in one culture class, the language is not the same, the point is that even though their tribes are different but we are still one Indonesian, we must uphold each other, not mock each other's ethnicity, religion, race. (Teacher interview, 9 November 2018); (8) Implement it by for example telling or giving photos of local wisdom around, especially those near the school. (Teacher interview, November 12, 2018); (9) When learning about social studies, yes, using the existing facilities and infrastructure I associate, for example, the culture here is what the culture of the region is, habits even though sometimes religion is not mandatory, for example, there will be mutual cooperation, cooperation and that our culture that we should not leave behind, he said, is this environmental facility in Bajubang for people to know tempeh, why don't we know that tempeh is famous. Doing so, this is social with the children. Apply it with question and answer. (Teacher interview, November 14, 2018); (10) Etnosocial is a new thing. In grade 3 there are no IPS. It can be included in social studies s`uch as from discourse about social stories. For example culture about traditional houses, daily habits. There are also familiar with regional culture such as the Jambi dance of betel lime dance, Jambi songs, at least children know 1 or 2 songs. So learning like this through the culture of Jambi Region (BDJ). At K13 the entry into the SBdP is like the cultural handicrafts in Jambi. (Teacher interview, November 15, 2018)

These comments indicate that the teacher has implemented ethnoconstivism knowledge in learning activities for students, with various learning strategies and methods.

The next point of the interview question is about the obstacles faced by the teacher in ethnoconstructivism implementation: (1) Tools with teaching materials. Sometimes afraid to ask for their parents. (Teacher interview, 30 October 2018); (2) is that if the Mersam tradition is not buried, it is not deep, especially since I am not a native person so I don't understand the customs too well. (Teacher interview, November 3, 2018); (3) If high-class children still know they don't know the name Mersam River because 
they have never been taken there. (teacher interview, November 3, 2018); (4) There are children who quickly catch what I say and some are slow, the solution that can be given to children are given enrichment assignments. And also from the parties as if this should be cooperation with parents. (Teacher interview, November 7, 2018); (5) Ads, the problem may be that many children do not understand, maybe the traditional house understands the traditional house, but like the native language, the child does not understand. (Teacher interview, November 7, 2018); (6) at a minimum, the child must be accompanied. If asked about social issues such as mutual cooperation, if we ask his father. You know the technical father in the field. Whereas the interviewee (child) was his mother so the results were not right. (Teacher interview, November 10, 2018); (7) One two is there. A motivation for learning children at home is lacking, only getting at school, so it might not be enough with the time at school because it's only how many hours. Besides that, the material in our scope is seldom that we want to convey it to children more difficult, the way. (teacher interview, November 12, 2018); (8) Constraints regarding technical guidelines, for example, skills require something that is unreachable on language material whose contents run a lot to Social Sciences. So I switch. For example about the regional culture here about making tempeh. The processing will be given a group assignment to report how to make tempeh. If you can, the child must look not from the story. (Teacher interview, November 14, 2018)

\section{CONCLUSION}

The results showed that the ethnoconstructivism knowledge of the teacher had an influence on the teacher's pedagogical competence. A teacher's age also affects pedagogical competence, but gender does not affect the teacher's pedagogical competence. Due to having a more mature age, a teacher will have more experience in learning.

\section{ACKNOWLEDGEMENTS}

The researcher expressed his gratitude to all elementary school teachers in Batanghari District, Muaro Jambi Regency and Jambi City for their participation and cooperation. The researcher also thanked the Education Office of Batanghari Regency, Muaro Jambi Regency and Jambi City for their support and cooperation. This research is funded by superior tertiary applied research grants from the Directorate General of strengthening research and Development of the Indonesian Ministry of Research, Technology and Higher Education (Ristekdikti) with Jambi universities through contract number 060 / SP2H / LT / DRPM / 2019 dated December 052018.

\section{REFERENCES}

[1] Astalini., Kurniawan, D. A., Perdana, R., \& Kurniasari, D., "Identification of student attitudes toward physics learning at Batanghari District High School," The Educational Review, vol. 2(9), pp. 475-484, USA 2018. https://doi.org/10.26855/er.2018.09.003

[2] Wood, K,. Education is Basic. New York: Taylor \& Francis Group. 2011.

[3] Gagné, R. M., The conditions of learning and Theory of Instruction Fourth Edition. Japan: CBS College Publishing. 1985.

[4] Kimani. G.N, Kara. A.M, \& Njagi. L.W., "Teacher factors influencing students' academic achievement in secondary schools In Nyandarua County," International Journal Of Education And Research, vol. 1(3), Kenya 2013. https://pdfs.semanticscholar.org/37ce/ede32c9ae377ef246bcfe37895be7c1a9062.pdf

[5] Obot, I. M., "Influence of teacher's competence in subject matter on students' interest in the learning of social studies education in Akwa Ibom State," International Journal of Teaching and Education, vol. 2(3), pp. 137, Nigeria. 2013. https://www.iises.net/download/Soubory/soubory-puvodni/pp137-154_ijoteV2N3.pdf

[6] Bruner, J. S., The process of education. Harvard University Press. 2009.

[7] Regulation of the Minister of National Education. Number 16 of 2007

[8] Rivera. A., Indigenous Knowledge And Cultural Competencies. In The Library Profession: From Theory To Practice. 2013.

[9] Fidan. N.K and Duman. T. "Classroom teachers' possession level of characteristics required by the constructivist approach," Education and Science, vol. 39(174). 2014. https://doi.org/10.15390/EB.2014.2027

[10] Colak. E., "Teachers' experiences in a professional learning community on the constructivist lesson planning: A case study among primary school teachers," Education and Science, vol. 42 (190), pp. 189-209, 2017. https://doi.org/10.15390/EB.2017.6911

[11] Joan. A.P. and Hendri. I. "Influence of teachers' age, marital status and gender on students' accademic achievement," Asian Journal Of Education Reseach, vol. 3(4), 2015.

[12] Shah. S.R, and Udgaonkar. U.S. "Influence of gender and age of teachers on teaching: Students perspective," International Journal of Current Microbiology and Applied Sciences, vol. 7(1), 2018. https://doi.org/10.20546/ijcmas.2018.701.293 
[13] Astalini, Kurniawan, D. A., Darmaji., Sitorus, L. R \& Perdana, R., "Characteristic of students attitude to physics In Muaro Jambi High School," Humanities \& Social Science Reviews, vol. 7(2), pp. 91-99, 2019. https://doi.org/1018510/hssr.2019.7210

[14] Hoquo. K. E. et al., "Impact of teacher-gender on primary students' achievement: a study at Malaysian Standpoint," Journal of Sociological Research, vol. 4(1), 2013.

[15] Sari. M. et al., "Analyzing teachers' perceptions of "female teacher" and "male teacher" within traditional gender roles," International Journal of Education and Research, vol. 4(3), 2016. http://www.ijern.com/journal/2016/March-2016/16.pdf

[16] Vanderstoep S.W and Johnston D.D. Research methods for everyday life. San Franeiseo : Jossey-Bass A Wiley Imprint, 2009.

[17] Neuman. W.L. Social Research Methods: Qualitative and Quantitative Approaches. United States of Americ: Pearson Education Limited, 2014.

[18] Creswell. J.W. Research Design Qualitative, Quantitative, And Mixed Method Aproach. Singapore: SAGE Publications Asia-Pacific, 2009.

[19] Miles. M.B, Huberman. A.M, \& Saldana. J., Qualitative Data Analisys A Methods Sourcebook. America: SAGE Publications, Inc, 2014.

[20] Momir. B. et.al., "The Importance of Cross-Cultural Knowledge. No 197. Procedia - Social and Behavioral Sciences," 2015. https://doi.org/10.1016/j.sbspro.2015.07.077

[21] Weaver. H.N., "The Elements of Cultural Competence: Applications with Native American Clients," Journal Of Ethnic \& Cultural Diversity In Social Work, vol. 3(1), 2004. https://doi.org/10.1300/J051v13n01_02

[22] Under, N., "Manifestations of epistemological theses of constructivism in the science and technology programs of Turkish elementary education," Education and Science, vol. 35(158), 2010.

[23] Ada. J.H. and Azisah .St. "The contribution of teachers' pedagogical competence toward the effectiveness of teaching of English at Mtsn Balang-Balang," ETERNAL (English, Teaching, Learning, and Research Journal), , vol. 2(2), 2016. https://doi.org/10.24252/Eternal.V22.2016.A5

[24] Akiri. A.A, and Ugborugbo. N.M. "An examination of gender's influence on teachers' productivity in secondary schools," Journal Social Science, vol. 17(3), 2008. https://doi.org/10.1080/09718923.2008.11892650

[25] Herman, R. S., "Elementary education majors' views on evolution: A comparison of undergraduate majors understanding of natural selection and acceptance of evolution," Electronic Journal of Science Education, vol. 20(6). pp21-44. 2016. https://eric.ed.gov/?id=EJ1188099

[26] Durkheim, E., Moral education. Courier Corporation. 2012.

[27] Suciu. A. and Mata. L. "Pedagogical competences - the key to efficient education," International Online Journal of Educational Sciences, vol. 3(2). 2011. http://www.acarindex.com/dosyalar/makale/acarindex-1423904375.pdf

[28] Asrial, A., Syahrial, S., Kurniawan, D. A., Subandiyo, M., \& Amalina, N., "Exploring obstacles in language learning among prospective primary school teacher," International Journal of Evaluation and Research in Education (IJERE), vol. 8(2), pp. 249-254, 2019. http://doi.org/10.11591/ijere.v8i2.16700

[29] Darmaji, D, Kurniawan, D. A, \& Irdianti, I., "Physics education students' science process skills. International Journal of Evaluation and Research in Education (IJERE), vol. 8(2), pp. 293-298, 2019. http://doi.org/10.11591/ijere.v8i2.16401

[30] Aimah. S, Ifadah. M, \& Bharati.D.A.L., "Building teacher's pedagogical competence and teaching improvement through lesson study," Arab World English Journal (AWEJ), vol. 8(1), 2017. https://dx.doi.org/10.24093/awej/vol8no1.6

[31] Tuluk, G, and Kepeceoglu, I. "Pre-service teachers' web pedagogical content knowledge and online information searching strategies," International Journal of Evaluation and Research in Education (IJERE), vol. 8(2), 229-236. 2019. http://doi.org/10.11591/ijere.v8i2.18771

[32] Lin.J.M, Wang.P, \& Lin. I.C., "Pedagogy technology: A two-dimensional model for teachers' ICT integration," Journal of Educational Technology. vol 43(1), pp. 97-108, 2012. https://dx.doi.org/10.1111/j.14678535.2010.01159

[33] Law, N., "Mathematics and science teachers' pedagogical orientations and their use of ICT in teaching," Educ Inf Technol, vol 14(1), 2009. DOI: https://dx.doi.org/10.1007/s10639-009-9094-Z

[34] Tentama, F., Subarjo, S, \& Abdillah., "M. H. Motivation to learn and social support determine employability among vocational high school students," International Journal of Evaluation and Research in Education (IJERE), vol. 8(2), 237-242, 2019. http://doi.org/10.11591/ijere.v8i2.18188

[35] Semin, F. K., "Competencies of principals in ensuring sustainable education: Teachers' views," International Journal of Evaluation and Research in Education (IJERE), vol. 8(2), pp. 201-212, 2019. http://doi.org/10.11591/ijere.v8i2.18273 